\author{
Iwona Foryśs \\ Uniwersytet Szczeciński \\ Ewa Putek-Szeląg** \\ Uniwersytet Szczeciński
}

\title{
WPŁYW DECYZJI PLANISTYCZNYCH \\ NA DECYZJE UCZESTNIKÓW RYNKU NIERUCHOMOŚCI NA PRZYKŁADZIE STARGARDZKIEGO RYNKU NIERUCHOMOŚCI
}

\begin{abstract}
Streszczenie
W artykule przeprowadzono analizę wpływu decyzji planistycznych na zmiany zachodzące na lokalnym rynku nieruchomości. Badane są etapy procesu planistycznego związane z: uchwaleniem studium kierunków zagospodarowania terenu, uchwałą gminy o przystąpieniu do sporządzenia miejscowego planu zagospodarowania przestrzennego, uchwałą o przyjęciu planu miejscowego, i skutki tych działań dla uczestników wybranego rynku nieruchomości w Stargardzie Szczecińskim, w województwie zachodniopomorskim. Celem badania jest identyfikacja wskazanych związków na wybranym rynku nieruchomości, na którym można wyodrębnić poszczególne etapy planowania przestrzennego, oraz siły i kierunku analizowanych związków. W analizie wykorzystano dane z Rejestru Cen i Wartości Starostwa Powiatowego, zasób danych statystyki i informacji publicznej oraz badania własne autorek.
\end{abstract}

Słowa kluczowe: analiza rynku nieruchomości, miejscowy plan zagospodarowania przestrzennego

* Adres e-mail: forys@wneiz.pl.

** Adres e-mail: wicheru@wneiz.pl. 


\section{Wprowadzenie}

Nieustanny rozwój i zmiany cywilizacyjne oraz rosnące zapotrzebowanie na miejsca przystosowane do realizacji zmieniających się potrzeb są przyczyną przekształceń fizycznej przestrzeni, w której funkcjonują zarówno pojedyncze jednostki, jak i całe społeczeństwa. Człowiek podejmuje próby kształtowania przestrzeni zgodnie z własnymi oczekiwaniami i potrzebami, a w dążeniu do spełnienia swoich celów uruchamia procesy przestrzenne, tworząc różnorodne struktury przestrzenne (Foryś, Nowak 2014, s. 13-15).

Celem artykułu jest identyfikacja związków na stargardzkim rynku nieruchomości, na którym można wyodrębnić poszczególne etapy planowania przestrzennego, ich wpływ na decyzje uczestników rynku oraz siły i kierunku analizowanych związków. W badaniu wykorzystano klasyczną analizę szeregów czasowych, szacując parametry funkcji trendu dla obrębu 16 oraz odrębnie dla całego miasta. W analizie wykorzystano dane z Rejestru Cen i Wartości Starostwa Powiatowego, zasób danych statystyki i informacji publicznej oraz badania własne autorek.

\section{System polityki przestrzennej}

System planowania przestrzennego wspiera przyjętą przez społeczeństwo strategię rozwoju. Obejmuje normowanie procesów przestrzennych, planowanie na poziomie operacyjnym, kontrolę obejmującą nadzór administracyjny i instytucjonalny, jak również realizację uznanych założeń oraz proponowanych rozwiązań, nadanie im formy graficznej lub opisowej przyjętej w danym systemie planowania.

Studium uwarunkowań i kierunków zagospodarowania przestrzennego jest dokumentem o charakterze programowym, obligatoryjnym dla każdej gminy. Stanowi zbiór dyrektyw określających zamierzenia w zakresie ładu przestrzennego na terenie gminy. Rolą studium jest wdrożenie spójnej koncepcji planistycznej dla całego obszaru gminy, obejmującej realne potrzeby rozwojowe gminy oraz dalekowzroczność w przyjętych koncepcjach zagospodarowania przestrzeni. Studium uwarunkowań i kierunków zagospodarowania przestrzennego jest dla właścicieli nieruchomości pierwszym sygnałem o potencjalnych funkcjach, jakie mogą w przyszłości być kreowane na ich nieruchomościach i w ich sąsiedztwie. 
Miejscowy plan zagospodarowania przestrzennego jest dokumentem, który nie musi odnosić się do całej powierzchni gminy, jego zakres zależy od uznania rady gminy. Nie ma też obowiązku jego sporządzania (jest fakultatywny z pewnymi wyjątkami), a działania dotyczące zmiany przeznaczenia terenu są podejmowane na podstawie decyzji o warunkach zabudowy i zagospodarowania terenu. Jest to akt prawa miejscowego wiążący wszystkich właścicieli nieruchomości, które obejmuje plan.

Analizując zachowania właścicieli nieruchomości i zmiany cenności gruntów wynikające z postępującego procesu planistycznego, należy zwrócić szczególną uwagę na skutki poszczególnych zmian, które wprowadza nowo uchwalany miejscowy plan zagospodarowania przestrzennego. Mogą być one zarówno pozytywne dla właścicieli gruntów objętych planem, gdy nowe zapisy rozszerzają ich uprawnienia, np. w kontekście zasad kształtowania zabudowy czy też wskaźników zagospodarowania terenu, jak i negatywne, gdy elementy planu miejscowego zawierają ograniczenia prawa osób dysponujących terenami objętymi planem.

W ustawie o planowaniu i zagospodarowaniu przestrzennym powiązano obniżenie wartości nieruchomości z przypadkami, kiedy w związku z uchwaleniem planu miejscowego albo jego zmianą korzystanie z nieruchomości (lub jej części) w sposób dotychczasowy stało się niemożliwe lub istotnie ograniczone. Wówczas właściciel tej nieruchomości lub jej użytkownik wieczysty może skierować do gminy żądanie, w którym będzie domagał się rekompensaty w postaci: odszkodowania za poniesioną szkodę, wykupienia nieruchomości lub jej części, w zależności od zakresu poczynionej szkody, albo zamiany nieruchomości lub jej części na inną.

W sytuacji podwyższenia wartości nieruchomości w wyniku zmiany w planie skutki finansowe (renta planistyczna) pojawiają się w przypadku, gdy właściciel lub użytkownik wieczysty zbył nieruchomość w ciągu pięciu lat od dnia, w którym plan miejscowy lub jego zmiana stały się obowiązujące. Maksymalna wysokość opłaty wynosić może 30\% wzrostu wartości nieruchomości. Stawka ta jest obligatoryjnym elementem każdego planu miejscowego. 


\section{Zmiana wartości nieruchomości w procesie planistycznym na przy- kładzie wybranego obszaru gminy Stargard Szczeciński}

W gospodarce rynkowej wartość przestrzeni może być utożsamiana $\mathrm{z}$ jej ceną rynkową, gdy może stanowić przedmiot obrotu rynkowego (np. grunt pod zabudowę), lub z cennością, która nie zawsze ma wymiar finansowy (np. cenność ekologiczna), ale zajmuje szczególne miejsce w hierarchii wartości społecznych.

Decyzje planistyczne determinują wykorzystanie gruntów niezabudowanych, a tym samym wpływają na ich wartość rynkową. Zarówno teoria lokalizacji, jak i badania naukowe prezentowane w literaturze światowej i krajowej (Krajewska, Źróbek, Šubic Kovač 2014; Friedmann 2004) wskazują na silną zależność decyzji planistycznych, sposobu wykorzystania gruntów oraz cenności nieruchomości gruntowych. Siła tych związków oraz ich kierunek są zmienne w czasie, mają również wymiar lokalny. Także skutki decyzji planistycznych są przesunięte w czasie.

Rysunek 1. Zmiana wartości nieruchomości w procesie inwestycyjnym

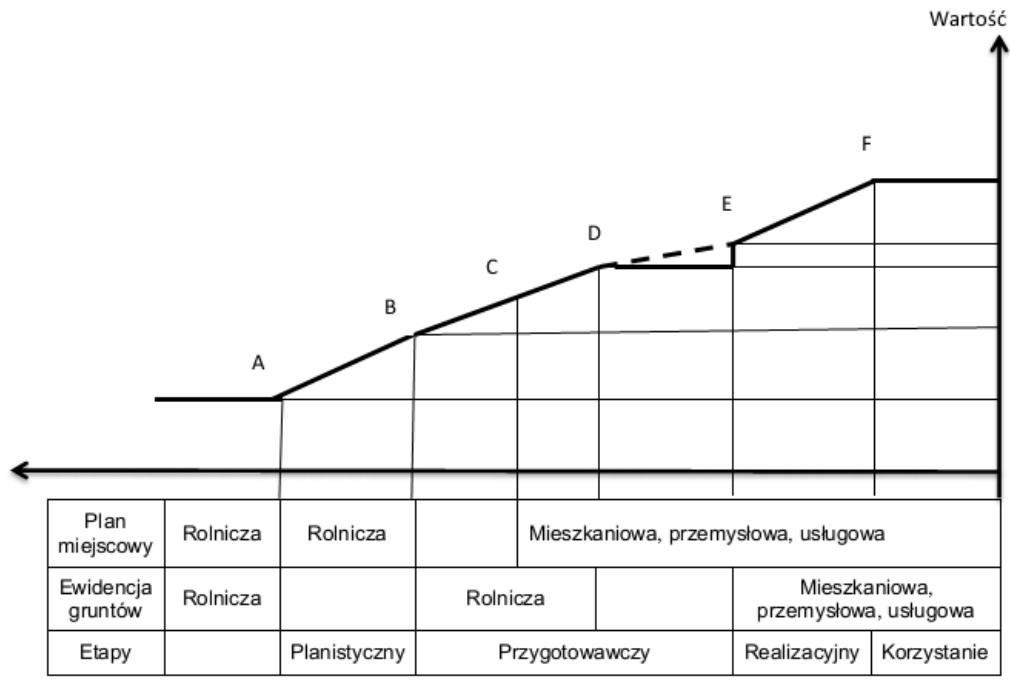

Źródło: obliczenia własne na podstawie Cymermann, Telega (2006, s. 12). 
Przyrost wartości nieruchomości w efekcie zmian planistycznych jest zazwyczaj najwyższy, gdy dotyczy przekształcenia funkcji rolniczej na funkcję mieszkaniową, przemysłową czy usługową (A-B). Kolejny istotny przyrost wartości ma miejsce w procesie podziału nieruchomości (B-C). Kolejny etap wzrostu wartości ma miejsce, gdy nieruchomość ma dostęp do infrastruktury technicznej (C-D), wreszcie ostatnim elementem wywołującym wzrost wartości jest wyłączenie z produkcji rolniczej (D-E). Następne wzrosty wartości nieruchomości są już efektem realizowanej na gruncie zabudowy, czyli właściwej inwestycji (E-F). Omawiany proces zilustrowano na rysunku 1.

Największe wzrosty wartości można zauważyć na gruntach niezurbanizowanych. Uchwalenie studium powoduje, że na danym terenie zwiększają się możliwości jego wykorzystania, co wpływa na jego wartość. Jedną z trudniejszych rzeczy jest ustalenie wpływu uchwalenia studium na wzrost wartości nieruchomości. Siła tego wpływu zależy od proponowanego przeznaczenia, szczegółowości zapisów i ich jednoznaczności.

Rozpoczęcie procedury uchwalania miejscowego planu zagospodarowania przestrzennego zazwyczaj przekłada się na widoczne zmiany cen nieruchomości gruntowych niezabudowanych lub zabudowanych, ale z zakładaną cenniejszą dla rynku funkcją. Intensywność i tempo zmian cen rynkowych tych nieruchomości jest uwarunkowane również popytem na nie na danym rynku, a także otoczeniem makroekonomicznym lokalnego rynku nieruchomości. Mogą one wpłynąć zarówno na osłabienie dynamiki wzrostu cen, jak i na przesunięcie tego procesu w czasie.

\section{Dane i metody badawcze}

W celu zbadania wpływu decyzji planistycznych na wartość gruntów niezabudowanych wybrano obszar badawczy, dla którego dysponowano zbiorem cen transakcyjnych w latach, kiedy miały miejsce zmiany planistyczne. Warunek ten spełniał obręb 16 miasta Stargard Szczeciński, ograniczony ulicami: Spółdzielczą, Niepodległości, Władysława Broniewskiego, zlokalizowany w południowej części miasta. Dla wyznaczonego obszaru zgromadzono informacje dotyczące transakcji gruntami niezabudowanymi zawartych w latach 2000-2014 z Rejestru Cen Wartości Starostwa Powiatowego w Stargardzie Szczecińskim. W celu porównania tendencji zmian cen $\mathrm{w}$ badanym obszarze $\mathrm{z}$ tendencjami $\mathrm{w}$ całym mieście zgromadzono rów- 
nież dane o transakcjach gruntami niezabudowanymi zawartych w latach 2000-2014 w pozostałych obrębach miasta.

W analizowanym procesie planistycznym można wskazać kilka istotnych dat:

a) 26 października 2000 r. - uchwała Studium uwarunkowań i kierunków zagospodarowania przestrzennego miasta Stargardu Szczecińskiego; w dokumencie tym dla obrębu 16 przewidziano głównie funkcje mieszkaniowe: M1, M2, tereny mieszkalnictwa jednorodzinnego o średniej intensywności i średnich standardach, tereny mieszkalnictwa wielorodzinnego o średniej i niskiej intensywności z towarzyszeniem usług bytowych i nieuciążliwych miejsc pracy;

b) 25 czerwca 2002 r. - uchwała nr XLVI/496/2002 Rady Miejskiej w Stargardzie Szczecińskim w sprawie przystąpienia do sporządzenia zmiany planu ogólnego zagospodarowania przestrzennego miasta Stargardu Szczecińskiego dotyczącej terenu w rejonie ulic: Władysława Broniewskiego, Armii Krajowej, 5 Marca oraz obejścia południowego miasta w ciągu drogi ekspresowej S-10;

c) 26 sierpnia 2003 r. - uchwała nr X/112/2003 Rady Miejskiej w Stargardzie Szczecińskim w sprawie zmiany planu ogólnego zagospodarowania przestrzennego miasta Stargardu Szczecińskiego dotyczącej terenu w rejonie ulic: Władysława Broniewskiego, Armii Krajowej, 5 Marca oraz obejścia południowego miasta w ciągu drogi ekspresowej S-10;

d) 26 października 2004 r. - uchwała o przystąpieniu do sporządzenia planu miejscowego w rejonie ulic: Spółdzielczej, Niepodległości, Władysława Broniewskiego; plan miejscowy obejmuje obszar położony w obrębie geodezyjnym 16, o powierzchni 39,0 ha;

e) 11-25 lipca 2006 r. - wyłożenie projektu planu do wiadomości publicznej w celu składnia uwag,

f) 26 września 2006 r. - uchwała w sprawie uchwalenia miejscowego planu zagospodarowania przestrzennego miasta Stargardu Szczecińskiego dotyczącego terenu w rejonie ulic: Spółdzielczej, Niepodległości, Władysława Broniewskiego;

g) 20 listopada 2006 r. - ogłoszenie uchwały w „Dzienniku Urzędowym Województwa Zachodniopomorskiego", nr 110, poz. 2149;

h) 20 grudzień 2006 r. - data wejścia w życie uchwały. 
Na zamieszczonej poniżej mapie stanowiącej załącznik graficzny omawianej uchwały z 20 grudnia 2006 r. (rysunek 2) na czerwono zaznaczono obszary o przeznaczeniu innym niż mieszkaniowe, a na jasnofioletowo obszar, którego uchwała nie dotyczy. Dla nieruchomości gruntowych stawka opłaty planistycznej wynosi $0 \%$, natomiast dla pozostałych nieruchomości przyjęto stawkę maksymalną $30 \%$.

W celu wykazania hipotezy badawczej wyznaczono średnie ceny transakcyjne gruntów niezabudowanych w obrębie 16 oraz z całego miasta, uzyskując dwa szeregi średnich cen transakcyjnych w latach 2000-2014. Wykorzystano analizę szeregów czasowych, szacując parametry funkcji trendu dla obrębu 16 oraz odrębnie dla całego miasta, a następnie sprawdzono hipotezę o równości parametrów przy zmiennej czasowej.

Rysunek 2. Załącznik graficzny do miejscowego planu zagospodarowania przestrzennego miasta Stargardu Szczecińskiego dotyczącego terenu w rejonie ulic: Spółdzielczej,

Niepodległości, Władysława Broniewskiego

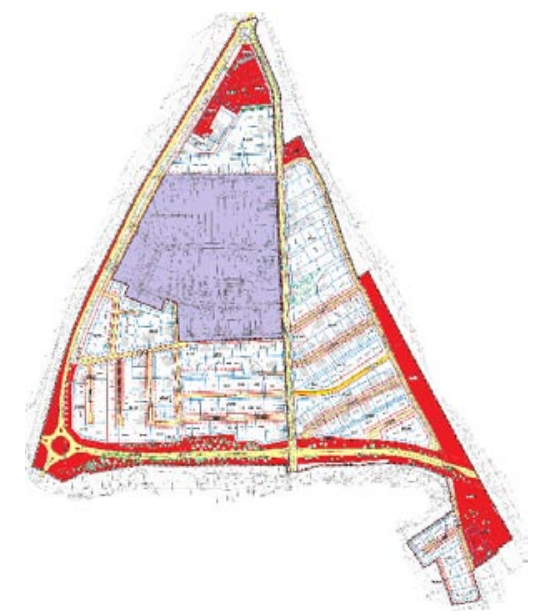

Źródło: uchwała nr XLVII/504/2006 Rady Miejskiej w Stargardzie Szczecińskim.

$\mathrm{Z}$ uwagi na funkcje badanego obszaru zapisane w studium i w planie miejscowym uzyskane wyniki dotyczą przede wszystkim skutków związanych z przekształceniem funkcji omawianych terenów z rolnej na mieszkaniową. Zmiany w miej- 
scowym planie zagospodarowania przestrzennego związane z budową obwodnicy stargardzkiej nie wpłynęły na tendencje na badanym ryku.

W latach 2000-2009 na terenie obrębu 16 nie zawierano rocznie więcej niż dziesięć transakcji dotyczących gruntów niezabudowanych, średnio sześć. W latach 2010-2014 średnio rocznie zawierano 23 takie transakcje na tym obszarze. Może to oznaczać, że większość właścicieli zdecydowała się na sprzedaż nieruchomości po 5 latach od momentu uchwalenia miejscowego planu zagospodarowania przestrzennego w celu uniknięcia opłaty w wysokości 30\% wzrostu wartości nieruchomości.

W latach 2000-2014 transakcje dotyczące gruntów niezabudowanych w obrębie 16 stanowiły 18,7\% wszystkich takich transakcji w mieście. Tak duży odsetek wynikał z lokalizacji obrębu 16 i kierunku rozwoju zabudowy mieszkaniowej miasta.

Jak widać na rysunku 3, w obrębie 16 można zauważyć tendencję wzrostową cen transakcyjnych gruntów niezabudowanych w latach 2000-2009. Tempo tych zmian było jednak różne. W latach od 2000 do 2004 r. (do momentu podjęcia uchwały o przystąpieniu do sporządzania planu) ceny gruntów niezabudowanych rosły średnio o $30 \%$ z roku na rok. Należy zwrócić uwagę również na zachowania kupujących grunty niezabudowane w 2005 r. i kolejnych latach - związane z wejściem Polski do Unii Europejskiej i powszechnie panującym przekonaniem o lawinowym wzroście cen nieruchomości, przywołując jako przykład Hiszpanię czy Irlandię (Taylor 2011, s. 9-15).

Między 2004 a 2007 r. (do momentu zakończenia budowy obwodnicy) ceny gruntów niezabudowanych rosły średnio o ponad $40 \%$ rocznie oraz w ostatnim okresie o ponad $73 \%$. Jest to oczywiście również efekt ogólnej koniunktury na rynku nieruchomości. W latach 2010-2014 nastąpił spadek cen i ich wahania, spowodowane dekoniunkturą na rynku nieruchomości. Podobna tendencja miała miejsce w całym mieście: stały wzrost średniej ceny gruntów niezabudowanych w latach 2000-2009 oraz wahania i spadki cen w latach 2010-2014. Przy czym można zauważyć mniejszą dynamikę zmian cen w mieście w stosunku do badanego obrębu 16.

Największe dysproporcje średnich cen transakcyjnych gruntów sprzedanych w badanym obrębie i całym mieście wystąpiły w 2008 oraz 2012 r., kiedy ceny gruntów w obrębie 16 były o ponad $30 \mathrm{z} ł / \mathrm{m}^{2}$ wyższe niż w całym mieście. Omawiany obręb 16 zyskał na wartości na skutek kolejnych uchwał wprowadzających 
miejscowe plany w sąsiedztwie tego obrębu, zwłaszcza związane z lokalizacją drogi ekspresowej S10.

Rysunek 3. Dynamika średnich cen transakcyjnych gruntów niezabudowanych w Stargardzie Szczecińskim w latach 2000-2014 [zł/m²]

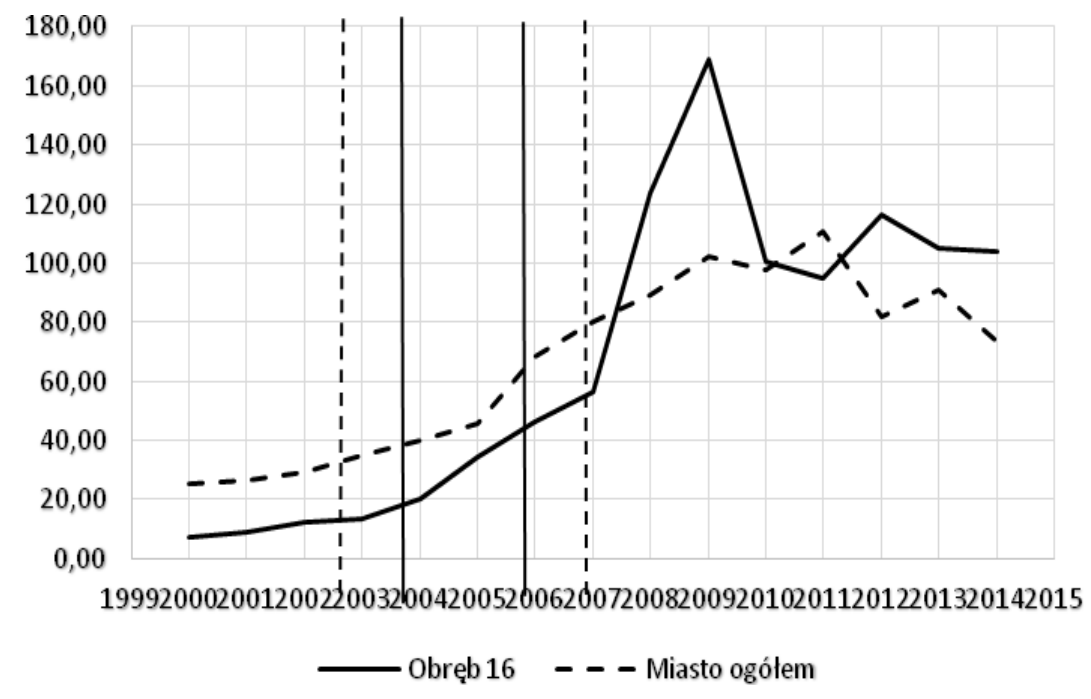

Źródło: obliczenia własne.

Uchwalenie studium nie wywołało znaczących zmian w cenach transakcyjnych. W latach 2000-2004 w obrębie 16 średnie ceny transakcyjne wzrosły z 7 z $/ \mathrm{m}^{2}$ do $20 \mathrm{zz} / \mathrm{m}^{2}$, natomiast w mieście z $25 \mathrm{zz} / \mathrm{m}^{2}$ do $40 \mathrm{zz} / \mathrm{m}^{2}$. Obowiązujące studium oraz podjęcie uchwały o przystąpieniu do sporządzania planu miejscowego w obrębie 16 spowodowało wzrost średnich cen z 34,19 zł/m² w 2005 r. do 46,25 zł/m² w $2006 \mathrm{r}$. (rysunek 4). 
Rysunek 4. Dynamika średnich cen transakcyjnych gruntów niezabudowanych w obrębie 16 w Stargardzie Szczecińskim w latach 2000-2009 [zz/m²]

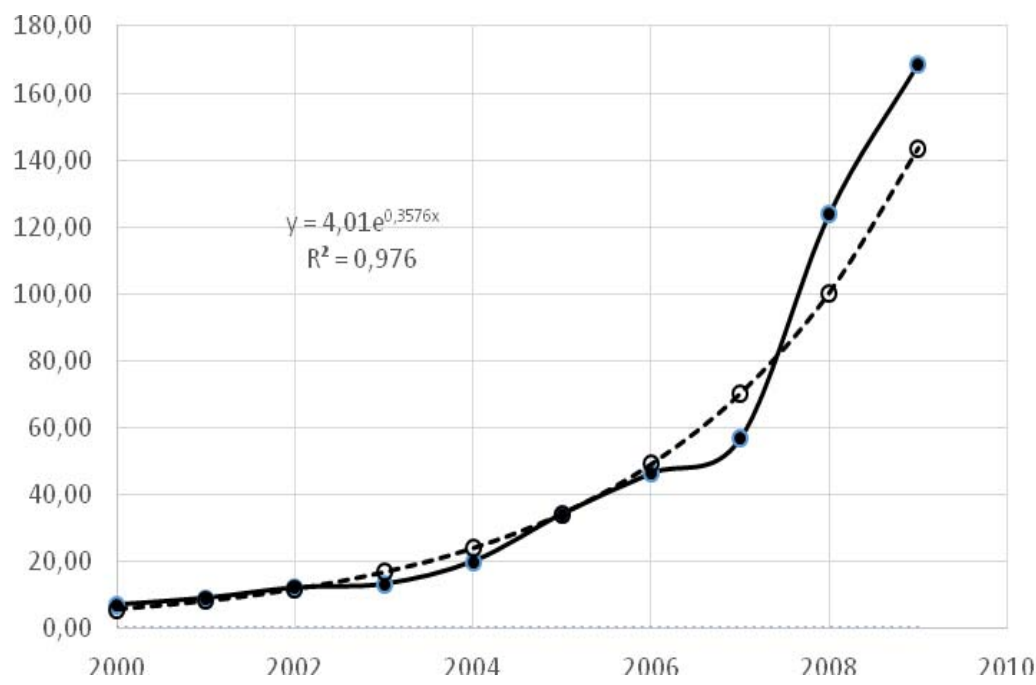

Źródło: obliczenia własne.

W tych samych latach 2005-2006 w całym mieście średnie ceny gruntów niezabudowanych zmieniły się odpowiednio z 45,80 zł/m² do 68,17 zł/m². W 2006 i kolejnym roku zauważalny był istotny wzrost cen, które osiągnęły poziom blisko $80 \mathrm{zl} / \mathrm{m}^{2}$ (rysunek 5).

Dla badanego obrębu 16 oraz dla całego miasta oszacowano parametry linii trendu średnich cen transakcyjnych gruntów niezabudowanych. W obu przypadkach najlepsze dopasowanie uzyskano dla funkcji wykładniczej (tabela 1).

Między średnimi cenami transakcyjnymi gruntów niezbudowanych sprzedanych w obrębie 16 w latach 2000-2014 a średnimi cenami gruntów niezabudowanych sprzedanych w całym mieście w tym samym okresie istnieje silna dodatnia zależność (współczynnik korelacji liniowej Pearsona wynosi 0,89). Oznacza to, że zmiany cen w badanym obszarze mają tę samą tendencję co do kierunku co w całym mieście. Na podstawie testu Durbina-Watsona nie można było jednoznacznie określić, czy w oszacowanych modelach występuje autokorelacja składnika losowego 
pierwszego rzędu. W tym celu zastosowano test istotności współczynnika korelacji. Jego wartość krytyczna wynosi 2,365, co oznacza, że współczynniki autokorelacji są nieistotne.

Rysunek 5. Dynamika średnich cen transakcyjnych gruntów niezabudowanych w Stargardzie Szczecińskim w latach 2000-2009 [zł/m²]

\section{Miasto ogółem}

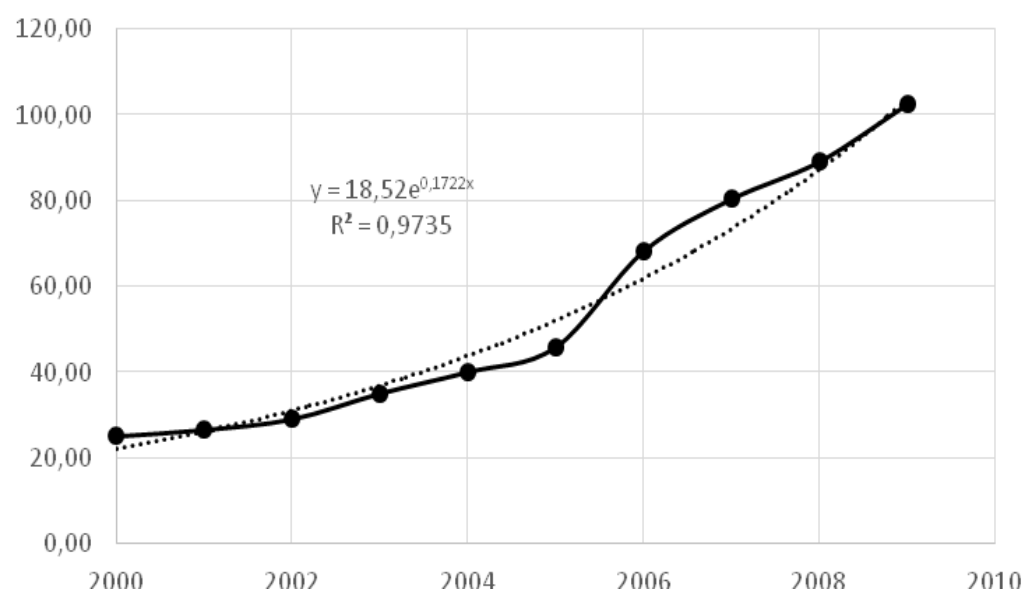

Źródło: obliczenia własne.

Tabela 1. Parametry oszacowania funkcji wykładniczej trendu średnich cen transakcyjnych gruntów niezabudowanych w latach 2000-2009 w Stargardzie Szczecińskim

\begin{tabular}{|l|c|c|}
\hline \multicolumn{1}{|c|}{ Parametry modelu } & Obręb 16 & Miasto \\
\hline$R^{2}$ & 0,9760 & 0,9735 \\
\hline Błąd standardowy & 0,1801 & 0,0912 \\
\hline Przecięcie & 4,0118 & 18,5281 \\
\hline Odchylenie standardowe & 0,1230 & 0,0624 \\
\hline Współczynnik przy zmiennej $t$ & 0,3576 & 0,1722 \\
\hline Odchylenie standardowe & 0,0198 & 0,0100 \\
\hline Statystyka Durbina-Watsona & 1,2829 & 1,1925 \\
\hline $\begin{array}{l}\text { Statystyka testu dla współczynnika } \\
\text { korelacji }\end{array}$ & 0,7048 & 0,7743 \\
\hline
\end{tabular}

Źródło: obliczenia własne. 


\section{Podsumowanie}

Zjawiska na rynku nieruchomości są zależne od otoczenia społeczno-gospodarczego całego rynku, stąd ocena wpływu wyłącznie decyzji planistycznych na zmiany cen na rynku nieruchomości jest niezmiernie trudna. Przyjmując zasadę ceteris paribus, można zauważyć pewne tendencje odzwierciedlające zachowania uczestników lokalnego rynku w reakcji na procesy planistyczne. Takie tendencje dotyczą m.in. zmian cen transakcyjnych na lokalnym rynku w odniesieniu do decyzji planistycznych, jak uchwalenie studium lub prace nad miejscowym planem zagospodarowania przestrzennego. Dodatkowo decyzje o zbyciu nieruchomości podejmowane są racjonalnie, tak aby zminimalizować dodatkowe koszty związane z opłatami planistycznymi.

Można zauważyć wyższą dynamikę wzrostu przeciętnych cen gruntów na terenie, na którym obowiązuje miejscowy plan zagospodarowania przestrzennego, w stosunku do całego miasta oraz wzrost atrakcyjności terenów mierzony liczbą transakcji w miarę postępowania prac planistycznych.

Na bazie uzyskanych informacji nie można jednoznacznie stwierdzić, że przyrost liczby transakcji począwszy od 2010 r. jest wynikiem wyłącznie zmian planistycznych, ponieważ nakłada się na ten okres hossa na rynku nieruchomości. Utrzymanie się zainteresowania nabywców obrębem 16 w okresie bessy na rynku nieruchomości, oczywiście przy spadku cen wynikającym z dekoniunktury, można jednak uznać za symptom przesuniętych w czasie pozytywnych skutków przeprowadzonego na tym terenie procesu planistycznego.

\section{Literatura}

Cymerman R., Telega T. (2006), Rola rzeczoznawcy majątkowego przy optatach planistycznych $i$ adiacenckich, „Rzeczoznawca Majątkowy”, nr 51, s. 11-13.

Foryś I. (2013), Gentrification on the Example of Suburban Parts of the Szczecin Urban Agglomeration, „Real Estate Management and Valuation”, vol. 21, nr 3, s. 5-14.

Foryś I., Nowak M. (2014), Zarzadzanie przestrzenia w gospodarowaniu nieruchomościami, Poltext, Warszawa.

Friedmann J. (2004), Strategic Spatial Planning and the Longer Range, „Planning Theory and Practice", vol. 5, nr 1, s. 49-67. 
Krajewska M., Źróbek S., Šubic Kovač M. (2014), The Role of Spatial Planning in the Investment Process in Poland and Slovenia, „Real Estate Management and Valuation”, vol. 22, nr 2, s. 52-66.

Uchwała nr XXVII/263/2000 Rady Miejskiej w Stargardzie Szczecińskim z 26 października 2000 r. Studium uwarunkowań i kierunków zagospodarowania przestrzennego miasta Stargardu Szczecińskiego.

Taylor S.F. (2011), Financial Crisis in the European Union: The Cases of Greece and Ireland, Virginia Polytechnic Institute and State University, Blacksburg.

Ustawa z dnia 27 marca 2003 r. o planowaniu i zagospodarowaniu przestrzennym, DzU z 2003 r., nr 80, poz. 647 ze zm.

Rejestr Cen i Wartości prowadzony przez Starostwo Powiatowe w Stargardzie Szczecińskim.

\title{
THE PLANNING DECISIONS IMPACT ON REAL ESTATE MARKET PARTICIPANTS DECISIONS
}

\begin{abstract}
The article analyses the influence of planning decisions on transforming local real estate markets. Three stages of the planning process are studied, especially referring to: the enactment of the planning studies of the directions of land use and the resolution act concerning the formation of the local spatial planning, the resolution accepting local planning, and the effects of these operations for the land value of the selected real estate market in Stargard Szczeciński in West-Pomeranian Voivodship. The object of this research is identification of the indicated relationships on a given real estate market based on respective spatial planning stages and determination of the strength and course of the analysed relationships. The research verifies hypothesis that the strength and the effects of planning decisions are direct and indirect reasons for price changes on the real estate market. This analysis uses the Price and Value Register of Poviat Council data along with statistical and public information data and the authors' own data.
\end{abstract}

Translated by Iwona Foryś

Keywords: analysis of real estate market, local zoning plan

JEL Codes: R52, R58, R140 
